\title{
Ruminal parameters and in-situ degradability of rations with wheat middling substitution for corn
}

\section{Parâmetros ruminais e degradabilidade in situ de rações com triguilho em substituição ao milho}

\author{
Vinicius Campachi Brito ${ }^{1 *}$; Leandro das Dores Ferreira da Silva ${ }^{2}$; Maria Carolina \\ Gonçalves de Arruda3; Dagiale Kelly de Souza Tagliatella4; Fernando Augusto \\ Grandis $^{1}$; Valter Harry Bumbieris Junior2; Lucas Camargo Ramos ${ }^{5}$; Higor Souza de \\ Camargo6; Vitor Hugo Pereira7; Ivone Yurika Mizubuti ${ }^{8}$
}

\section{Highlights}

Substitution of corn by wheat middling did not alter the ruminal parameters. Increased wheat middling in the rations resulted in greater dry matter degradability. Wheat middling can be used as a substitute for corn in cattle feed.

\begin{abstract}
This study aimed to evaluate the effect of substituting corn with wheat middling on the in-situ degradability of foods and ruminal parameters of cattle. The experiment was conducted at the Ruminant Studies Unit and the Laboratory of Food Analysis and Animal Nutrition of Londrina State University. Five rumen-fistulated cattle with an average weight of $521 \pm 38.22 \mathrm{~kg}$ were housed in individual stalls. The experimental design used was a Latin square with five treatments (100\% C, 75\% C 25\% WM, 50\% C 50\% WM, 25\% C 75\% WM, and $100 \% \mathrm{WM})$ and five periods of 25 days each. The $\mathrm{pH}$ and ammoniacal nitrogen $\left(\mathrm{N}^{-} \mathrm{NH}_{3}\right)$ concentration in ruminal fluid was measured before feeding and $2,4,6$, and $8 \mathrm{~h}$ after feeding in subdivided parcels. The in-situ degradability of dry matter (DM), organic matter (OM), crude protein (CP), neutral detergent fiber (NDF), and acid detergent fiber (ADF) were determined by incubating silage samples and measuring concentrates in the rumen of cattle. The levels of substitution of corn by wheat middling did not alter the $\mathrm{pH}$ and $\mathrm{N}-\mathrm{NH}_{3}$ values but was influenced by the collection time. The $\mathrm{N}-\mathrm{NH}_{3}$ presented quadratic behavior with a point of maximum

1 PhD in Animal Science, State University of Londrina, UEL, Londrina, PR, Brazil. E-mail: viniciuscampachi_brito@hotmail. com; fernando grandis@yahoo.com.br

2 Profs. PhD's, Zootechnical Department, UEL, Londrina, PR, Brazil. E-mail: leandro@uel.br; jrbumbieris@uel.br

3 Student, Doctoral Course of the Graduate Program in Zootecnia, Paulista State University, UNESP, Jaboticabal, SP, Brazil. E-mail: goncalves.arruda@unesp.br

4 Master in Animal Science, UEL, Londrina, PR, Brazil. E-mail: dagiale_tagliatella@hotmail.com

5 Student, Veterinary Residency, State University of Northern Paraná, UENP, Bandeirantes, PR, Brazil. E-mail: lucasramos97@gmail.com

6 Student, Veterinary Residency, UEL, Londrina, PR, Brazil. E-mail: higorsdecamargo@gmail.com

7 Student, Veterinarian, UEL, Londrina, PR, Brazil. E-mail: vitor.vetuel@gmail.com

8 Profa Dra Senior, Department of Zootechnical, Graduate Program in Animal Science, UEL, Londrina, PR, Brazil, E-mail: mizubuti@uel.br

* Author for correspondence
\end{abstract}

Received: May 12, 2020 - Approved: Mar. 25, 2021 
rumen concentration (5.31 $\left.\mathrm{mgdL}^{-1}\right)$ reached $1.12 \mathrm{~h}$ after feeding. The $\mathrm{pH}$ presented quadratic behavior with a point of minimum (6.04) reached $4.32 \mathrm{~h}$ after feeding. The effective degradability (ED) of DM with 2, 5 and $8 \% \mathrm{~h}^{-1}$ of passage rate was influenced by the substitution of corn by wheat middling, with increasing linear behavior. The ED $2 \% \mathrm{~h}^{-1}$ varied from $46.19 \%$ to $50.24 \%$, the ED $5 \% \mathrm{~h}^{-1}$ varied from $33.76 \%$ to $38.68 \%$, and the ED $8 \% \mathrm{~h}^{-1}$ values ranged from $28.16 \%$ to $32.92 \%$ for the $100 \% \mathrm{C}$ and $100 \% \mathrm{WM}$ treatments. Higher values, for treatments with higher levels of substitution of corn by wheat middling, occurred owing to the lower fiber content and to the largest soluble fractions and degradation rate of DM in rations with wheat middling. The ED of CP and NDF with passage rates of 2,5 and $8 \% \mathrm{~h}^{-1}$ presented quadratic behavior. The ED 2, 5 and $8 \% \mathrm{~h}^{-1}$ of CP presented maximums of $75.9 \%, 77.9 \%$, and $86.2 \%$, with averages of $52.02 \%, 45.93 \%$, and $42.23 \%$, respectively. The ED 2, 5 and $8 \% \mathrm{~h}^{-1}$ of NDF presented minimum points of $29.6 \%, 34.7 \%$, and $35.2 \%$, with averages of $41.60 \%, 33.43 \%$, and $27.76 \%$, respectively. Wheat middling can be used for total substitution of corn without damaging ruminal $\mathrm{pH}$ and $\mathrm{N}-\mathrm{NH}_{3}$, in addition to improving the degradability of rations.

Key words: Cattle. Confinement. Coproducts. Ruminants.

\section{Resumo}

Objetivou-se com este estudo avaliar o efeito da substituição do milho por triguilho sobre a degradabilidade in situ das rações e os parâmetros ruminais de bovinos. O experimento foi conduzido na Unidade de Estudos de Ruminantes (UNER) e no Laboratório de Análises de Alimentos e Nutrição Animal (LANA) da Universidade Estadual de Londrina. Foram utilizados cinco bovinos fistulados no rúmen, com peso médio de $521 \pm 38,22 \mathrm{~kg}$, alojados em baias individuais. O delineamento experimental utilizado foi o quadrado latino, com cinco tratamentos, sendo as proporções de milho e triguilho (100\% M, 75\% M 25\% T, 50\% M $50 \%$ T, 25\% M 75\% T e 100\% T) e cinco períodos de 25 dias cada. O pH e nitrogênio amoniacal $\left(\mathrm{N}^{\left.-\mathrm{NH}_{3}\right)}\right.$ do líquido ruminal foram mensurados antes da alimentação e 2, 4, 6 e 8 horas após alimentação, em parcelas subdivididas. A degradabilidade in situ da matéria seca (MS), matéria orgânica (MO), proteína bruta (PB), fibra em detergente neutro (FDN) e fibra em detergente ácido (FDA) foram determinadas com a incubação das amostras de silagem e concentrados no rúmen dos animais. Os teores de substituição do milho pelo triguilho não influenciaram os valores de $\mathrm{N}-\mathrm{NH}_{3}$ e $\mathrm{pH}$ ruminal, mas os mesmos foram influenciados pelos tempos de coleta. $\mathrm{O} \mathrm{N}-\mathrm{NH}_{3}$ apresentou comportamento quadrático com ponto de máxima concentração no rúmen (5,31 $\left.\mathrm{mgdL}^{-1}\right) 1 \mathrm{~h} 12$ após a alimentação. $\mathrm{O}$ pH apresentou comportamento quadrático com ponto de mínima $(6,04) 4$ h32 após a alimentação dos animais. A degradabilidade efetiva (DE) da MS com 2,5 e $8 \% \mathrm{~h}^{-1}$ de taxa de passagem foram influenciadas pela substituição do milho por triguilho, observando comportamento linear crescente. A DE $2 \% \mathrm{~h}^{-1}$ apresentou variação de 46,19\% a 50,24\%, a DE 5\% ${ }^{-1}$ variou de $33,76 \%$ a $38,68 \%$ e a DE $8 \% h^{-1}$ apresentou valores de $28,16 \%$ a $32,92 \%$ para os tratamentos $100 \% \mathrm{M} \mathrm{e}$ $100 \%$ T. Os valores superiores, observados nos tratamentos com maiores teores de substituição do milho pelo triguilho, ocorreram devido ao menor teor de fibra e às maiores frações solúveis e taxa de degradação da MS nas rações com triguilho. As DE da PB e FDN com 2, 5 e $8 \% \mathrm{~h}^{-1}$ de taxa de passagem apresentaram comportamento quadrático. As DE 2,5 e $8 \% \mathrm{~h}^{-1}$ da PB apresentaram pontos de máxima em 75,9\%, 77,9\% e 86,2\% com médias de 52,02\%, 45,93\% e 42,23\%, respectivamente. As DE 2, 5 e 8\% ${ }^{-1}$ da FDN apresentaram pontos de mínima em 29,6\%, 34,7\% e 35,2\% com médias de 41,60\%, 33,43\% e 27,76\%, respectivamente. $\mathrm{O}$ triguilho pode ser utilizado em substituição total ao milho sem prejudicar o $\mathrm{pH}$ e N-NH $\mathrm{N}_{3}$ ruminal, além de melhorar a degradabilidade das rações.

Palavras-chave: Bovinos. Confinamento. Coprodutos. Ruminantes. 


\section{Introduction}

Corn is widely used as an energy source in animal feed; although the production of safrinha corn contributes to the maintenance of cereal prices price increases are observed after the end of its harvest, imposing greater pressure on the producers who use it on a large scale. There is, therefore, a need to seek new energy sources for cattle diets (Socreppa et al., 2015).

The inclusion of agro-industry byproducts in the diet of animals is an option to reduce feed costs, maintain production levels, and provide better profitability to ranchers. Among the possibilities of replacing corn in the formulation of feed for ruminants, an interesting alternative is wheat middling, which can be classified in three different ways. The most common and least expensive wheat middling is represented by the material retained in the sieves with mesh sizes between 1.5 and 1.75 $\mathrm{mm}$, resulting from the wheat cleaning process. The best quality wheat middling breads are represented by grains in contact with the walls and floors of the silos (resulting from the disposal of wheat for shipping) and by clean, dry grains of insufficient quality.

Diet and other related variables, such as the roughage:concentrate ratio and the quantity and quality of the food, affect the hydrogen potential $(\mathrm{pH})$ and ammoniacal nitrogen concentration $\left(\mathrm{N}^{-} \mathrm{NH}_{3}\right)$ present in the rumen. These are considered indicators of the rumen environment, as they influence microbial growth. A study of rumen dynamics demonstrated that diet could change these ruminal parameters and evaluated the need for possible changes in the nutritional management of the herd (Silva-Marques et al. 2015).
In ruminant diet adequacy systems, information on the proportions of food fractions and their digestion rates is necessary to maximize microbial efficiency, synchronize the availability of energy and protein in the rumen, and reduce losses from rumen fermentation (Mizubuti et al., 2014).

To evaluate food, the in-situ degradability technique has been used as an accurate and cost effective method that aims to determine the disappearance of nutrient fractions in food over time. The disappearance curves of each fraction describe the ruminal degradation kinetics and, therefore, are important for explaining the relationships between ingestion, digestion, and performance of ruminants (Muniz et al., 2012).

Therefore, the objective of this study was to evaluate the effect of replacing corn with wheat middling bran on the in-situ degradability of feed and ruminal parameters of cattle.

\section{Material and Methods}

The experiment was conducted in accordance with the guidelines issued by the National Council for the Control of Animal Experimentation (CONCEA) and approved by the Ethics Committee on the Use of Animals at the State University of Londrina (CEUA-UEL), circular letter CEUA N ${ }^{\circ}$ 44/2016.

The study site was at the Ruminant Studies Unit (UNER), located at Fazenda Escola and at the Laboratory of Food Analysis and Animal Nutrition (LANA) of the Animal Science Department of UEL.

Five diets were evaluated; the control diet included only corn as an energetic food 
and the others had four different ratios of corn: wheat middling in concentrated cattle diets.

The treatment diets were: 100\% C concentrated feed with corn as the main energetic ingredient; $75 \%$ C, 25\% WM concentrated feed with the main energetic ingredient composed of $75 \%$ corn and $25 \%$ wheat middling in DM; $50 \%$ C 50\% WM concentrated feed with the main energetic ingredient composed of $50 \%$ corn and $50 \%$ wheat middling in DM; $25 \%$ C $75 \%$ WM concentrated feed with the main energetic ingredient composed of $25 \%$ corn and $75 \%$ wheat middling in DM; $100 \%$ WM concentrated feed with wheat middling as the main energetic ingredient (Table 1).

\section{Table 1}

\section{Proportion of ingredients in experimental diets (\% DM)}

\begin{tabular}{|cccccc|}
\hline \multirow{2}{*}{ Items (\%) } & \multicolumn{5}{c|}{ Substitutions of corn by wheat middling ${ }^{1}$} \\
\cline { 2 - 6 } & $100 \%$ C & $75 \%$ C 25\% WM & $50 \%$ C 50\% WM & $25 \%$ C 75\% WM & $100 \%$ WM \\
\hline Corn & 46.94 & 38.26 & 24.68 & 11.95 & 0 \\
\hline Wheat Middling & 0 & 12.97 & 25.09 & 36.45 & 52.89 \\
\hline Soybean Meal & 7.38 & 3.11 & 4.59 & 5.98 & 1.51 \\
\hline Soybean & 4.80 & 4.80 & 4.80 & 4.80 & 4.80 \\
\hline Calcitic Limestone & 0.70 & 0.70 & 0.70 & 0.70 & 0.69 \\
\hline Mineral Mixture* & 0.16 & 0.16 & 0.16 & 0.16 & 0.16 \\
\hline Corn Silage & 40.00 & 40.00 & 40.00 & 40.00 & 40.00 \\
\hline
\end{tabular}

${ }^{1} 100 \%$ C $=100 \%$ corn; $75 \%$ C 25\% WM = 75\% corn and 25\% wheat middling; 50\% C, 50\% WM, 50\% corn, and 50\% wheat middling; $25 \% \mathrm{C} 75 \% \mathrm{WM}=25 \%$ corn and $75 \%$ wheat middling; $100 \% \mathrm{WM}=100 \%$ wheat middling. Mineral Mixture ${ }^{*}, \mathrm{Ca}=218.0 \mathrm{~g} \mathrm{~kg}^{-1} ; \mathrm{P}=156.0 \mathrm{~g} \mathrm{~kg}^{-1} ; \mathrm{S}=52.0 \mathrm{~g} \mathrm{~kg}^{-1} ; \mathrm{Mg}=39.0 \mathrm{~g} \mathrm{~kg}^{-1} ; \mathrm{Co}=180.0 \mathrm{mg} \mathrm{kg}^{-1} ; \mathrm{Cu}=2,480.0 \mathrm{mg} \mathrm{kg}{ }^{-1} ; \mathrm{Cr}$ $=40.0 \mathrm{mg} \mathrm{kg}^{-1} ; \mathrm{I}=180.0 \mathrm{mg} \mathrm{kg}^{-1} ; \mathrm{Mn}=4,117.0 \mathrm{mg} \mathrm{kg}^{-1} ; \mathrm{Se}=55.0 \mathrm{mg} \mathrm{kg}^{-1} ; \mathrm{Zn}=9,800.0 \mathrm{mg} \mathrm{kg}^{-1}$.

Prior to the beginning of the experiment, the cattle underwent a $21 \mathrm{~d}$ adaptation period to the place, feeding times, and roughage:concentrate consisting of corn silage, and concentrated feed of corn and soybean meal.

The experiment was carried out in five experimental periods of $25 \mathrm{~d}$ each; 10 $\mathrm{d}$ of adaptation, $11 \mathrm{~d}$ of data collection, and $4 \mathrm{~d}$ of rest. On the rest days the cattle were on pastures of the genus Brachiaria during the day and in pens at night where they were supplemented with the respective treatment feed concentrates they would receive in the subsequent experimental period.

Five Girolando cattle with an average age of 40 months and average weight of 521 $\pm 38.22 \mathrm{~kg}$ were used. They were endowed with ruminal fistula and cannulated. The cattle remained housed in individual $4.5 \mathrm{~m} 2$ pens, provided with cover, drinking fountains, and individual feeders.

Corn silage was used as a source of bulky food, and the concentrated rations 
included: corn and/or wheat middling, soybean meal, soybean ground in a mill with a $1.5 \mathrm{~mm}$ sieve diameter, and calcitic limestone and mineral core.
The ingredients were analyzed (Table 2) according to the proportions of dry matter (DM), crude protein $(\mathrm{PB})$, ether extract $(\mathrm{EE})$, mineral matter (MM), organic matter (MO), neutral detergent fiber (NDF), and acid detergent (FDA) (Van Soest, 1994).

Table 2

Chemical-bromatological composition of the ingredients of the experimental diets

\begin{tabular}{|cccccccc|}
\hline (\%) & Corn & $\begin{array}{c}\text { Wheat } \\
\text { Middling }\end{array}$ & $\begin{array}{c}\text { Soybean } \\
\text { Meal }\end{array}$ & Soybean & $\begin{array}{c}\text { Corn } \\
\text { Silage }\end{array}$ & $\begin{array}{c}\text { Calcitic } \\
\text { Limestone }\end{array}$ & $\begin{array}{c}\text { Mineral } \\
\text { Mixture }\end{array}$ \\
\hline DM & 89.02 & 87.39 & 88.64 & 89.22 & 27.26 & 99.00 & 99.00 \\
CP & 9.21 & 13.61 & 49.72 & 36.40 & 8.00 & - & - \\
EE & 2.94 & 3.15 & 4.45 & 15.64 & 3.20 & - & - \\
MM & 2.52 & 3.30 & 6.84 & 10.81 & 5.64 & 99.00 & 99.00 \\
\hline OM & 97.48 & 96.70 & 93.16 & 89.19 & 94.36 & 1.00 & 1.00 \\
\hline FDN & 23.78 & 20.01 & 9.28 & 23.07 & 46.46 & - & - \\
\hline FDA & 8.51 & 5.92 & 7.77 & 18.06 & 28.26 & - & - \\
\hline DDM $^{*}$ & 74.61 & 75.87 & 79.44 & 74.85 & 67.05 & & - \\
TDN $^{* *}$ & 71.49 & 72.54 & 75.50 & 71.69 & 64.20 & - & - \\
\hline
\end{tabular}

MS = Dry Matter; $\mathrm{CP}=$ Crude Protein; $\mathrm{EE}=$ Ether Extract; $\mathrm{MM}=$ Mineral Matter; OM = Organic Matter; NDF = Neutral Detergent Fiber; ADF = Acid Detergent Fiber; DDM = Digestibility of Dry Matter, calculated according to Cappelle et al. (2001); TDN = Total Digestible Nutrients, calculated according to the equation suggested by Cappelle et al. (2001).

The total digestible nutrients (NDT) were estimated using the equations proposed by Cappelle et al. (2001) and were based on the DM food composition. The following equations were considered: \% NDT $=9.6134+0.8294$ * DMS (R2 = 0.98), for concentrates; 0\% NDT $=10.43+0.8019 *$ DMS $(R 2=0.89)$, for corn silage. The digestibility of DM (DMS) was calculated using the NDF of the ingredients (Cappelle et al., 2001), where DMS = 82.5353$0.3333 *$ NDF $(R 2=0.87)$.

Safrinha corn was produced in the municipality of Leópolis-PR and transported to UEL where the material was compacted, sealed with plastic tarpaulin, and covered with a $50 \mathrm{~cm}$ layer of straw to remove oxygen from the silo environment and protect it from rain.

The silage was sealed for $120 \mathrm{~d}$. On opening, three samples of the silage were collected for $\mathrm{pH}$ analysis (Playne \& McDonald, 1966), where an average of 3.8 was obtained.

To ensure compliance with the nutritional requirements proposed by the National Research Council [NRC] (1996) for an average daily gain of $1.0 \mathrm{~kg}$, the experimental diets had to remain isoproteic and were, therefore, composed of $60 \%$ concentrate and $40 \%$ roughage in DM (Table 3 ). 
Table 3

Chemical-bromatological composition of experimental diets

\begin{tabular}{|cccccc|}
\hline & \multicolumn{5}{c|}{ Substitutions of corn by wheat middling ${ }^{1}$} \\
\cline { 2 - 6 } Items & $100 \%$ C & $75 \%$ C $25 \%$ WM & $50 \%$ C 50\% WM & 25\% C 75\% WM & 100\% WM \\
\hline DM (\%) & 65.16 & 65.21 & 64.84 & 65.04 & 64.39 \\
\hline CP (\%) & 13.43 & 13.41 & 13.69 & 13.83 & 13.47 \\
\hline EE (\%) & 4.16 & 3.67 & 3.51 & 3.22 & 2.94 \\
\hline MM (\%) & 6.28 & 5.84 & 5.41 & 5.73 & 5.42 \\
\hline OM (\%) & 93.72 & 94.16 & 94.59 & 94.27 & 94.58 \\
\hline NDF (\%) & 32.10 & 30.11 & 29.37 & 28.00 & 28.00 \\
\hline ADF (\%) & 17.15 & 16.77 & 16.34 & 15.46 & 14.80 \\
\hline Lignin (\%) & 1.172 & 1.136 & 0.776 & 0.776 & 0.89 \\
\hline NDIP (\%CP) & 8.58 & 8.57 & 8.41 & 8.41 & 8.37 \\
\hline ADIP (\%CP) & 4.94 & 5.00 & 5.00 & 5.02 & 5.02 \\
\hline DDM & 71.84 & 72.50 & 72.75 & 73.20 & 73.20 \\
\hline TDN (\%) & 72.59 & 73.30 & 73.56 & 74.05 & 74.05 \\
\hline
\end{tabular}

${ }^{1} 100 \% \mathrm{C}=100 \%$ corn; $75 \%$ C 25\% WM = 75\% corn and 25\% wheat middling; 50\% C 50\% WM = 50\% corn and 50\% wheat middling; $25 \%$ C 75\% WM = 25\% corn and 75\% wheat middling; $100 \% \mathrm{WM}=100 \%$ wheat middling; DM = Dry Matter; $\mathrm{CP}=$ Crude Protein; $\mathrm{EE}=$ Ether Extract; $\mathrm{MM}=$ Mineral Matter; $\mathrm{OM}=$ Organic Matter; NDF = Neutral Detergent Fiber; ADF = Acid Detergent Fiber; NDIP = Neutral Detergent Insoluble Protein; ADIP = Acid Detergent Insoluble Protein; DDM = Digestibility of Dry Matter, calculated according to Cappelle et al. (2001); TDN = Total Digestible Nutrients, calculated according to the equation suggested by Cappelle et al. (2001).

Three samples of concentrate and silage were collected for the bromatological analysis of the experimental diets. The silage samples were weighed and subsequently predried using an oven with forced air circulation $\left(55 \pm 5^{\circ} \mathrm{C}\right)$ for $72 \mathrm{~h}$ in the laboratory.

The diets were analyzed for the percentage of $\mathrm{DM}, \mathrm{PB}, \mathrm{EE}, \mathrm{MM}, \mathrm{FDN}, \mathrm{FDA}$, lignin, and estimates of MO (Mizubuti, Pinto, Ramos, \& Pereira, 2009), neutral detergent insoluble protein (PIDN) and acid (PIDA) in a percentage of CP (Silva \& Silva, 2013). Estimates of the DMS and NDT (Cappelle et al., 2001) of the total ratios were carried out.

The cattle were fed daily at 8:00 $\mathrm{h}$ and $17: 00 \mathrm{~h}$. The leftovers were kept above $10 \%$ of the total consumed and, weighed daily before the morning treatment period.

Measurements of ammoniacal nitrogen $\left(\mathrm{N}-\mathrm{NH}_{3}\right)$ and ruminal $\mathrm{pH}$ were performed on the 12th day of each $25 \mathrm{~d}$ period, whereby $100 \mathrm{~mL}$ of ruminal fluid was collected from each animal at 2-hour intervals between collections. The first collection of ruminal fluid was carried out at 8:00 am (before feeding), which was considered as zero time (0) and the other collections were at 2, 4, 6, and $8 \mathrm{~h}$ after feeding.

The ruminal fluid samples were collected at four different points of the rumen, filtered through cotton fabrics and homogenized for immediate $\mathrm{pH}$ reading. With 
the aid of a digital pot, $50 \mathrm{~mL}$ of the ruminal fluid samples, were acidified with $1 \mathrm{~mL} 50 \%$ sulfuric acid, packed in Falcon tubes with airtight lids, and immediately frozen $-80{ }^{\circ} \mathrm{C}$ for further analysis of $\mathrm{N}-\mathrm{NH}_{3}$.

After thawing, $\mathrm{N}-\mathrm{NH}_{3}$ concentrations were determined by centrifuging and distilling $2 \mathrm{~mL}$ of the supernatant from each sample and adding $5 \mathrm{~mL}$ of $\mathrm{KOH} 2 \mathrm{~N}$ in a Kjeldahl apparatus. The distillate was received in $10 \mathrm{~mL}$ of $2 \% \mathrm{H}_{3} \mathrm{BO}_{3}$ until a final volume of $50 \mathrm{~mL}$ was reached. This was followed by titration with HCL $0.005 \mathrm{~N}$, according to the (Fenner, 1965).

The samples were incubated for in situ degradability analysis from day 18 to 21 of each experimental period.

The ruminal degradability of $\mathrm{DM}, \mathrm{MO}$, PB, FDN, and FDA of the rations, and their respective degradation rates, were determined in situ in non-woven bags (TNT) with a weight of $10 \mathrm{mg}$ per $\mathrm{cm}^{2}$ and dimensions of $14 \times 7 \mathrm{~cm}$.

The TNT sachets were labelled, weighed, and each received $7 \mathrm{~g}$ of silage or concentrate samples and were then heatsealed. The feed samples had been crushed in a mill with a $2 \mathrm{~mm}$ sieve diameter. Weighing was performed on a precision scale to four decimal places.

For incubation, the TNT sachets containing feed samples were put in nylon bags and placed in the rumen of each individual animal and weighted with $200 \mathrm{~g}$ chains to ensure the bags remained in contact with the rumen.

Theincubationtimesforbagscontaining four sachets of silage and concentrate mixes were: $0,2,6$, and $12 \mathrm{~h}$. For those containing five sachets, the incubation times were; $24,48,72$, and $96 \mathrm{~h}$. The zero time bags (0) did not come into contact with the rumen; but were exposed to the washing and drying procedures with the others.

After the incubation period, the bags were removed from the rumen and placed in ice water for $15 \mathrm{~min}$. They were then washed in a washing machine in five cycles of one min each.

Subsequently, the bags were dried in an oven with forced air circulation $\left(55 \pm 5^{\circ} \mathrm{C}\right)$ for $72 \mathrm{~h}$ and then weighed. The percentage of disappearance of DM, MO, PB, NDF, and FDA by incubation time was calculated for the food residue after ruminal incubation.

The data on the disappearance of nutrients were adjusted by non-linear regression, which predicted the potential degradability $(y=S D)$ of the food using the model proposed by Ørskov and McDonald (1979).

The effective degradability of DM was calculated using the equation described by Ørskov and McDonald (1979), in which: effective degradability $=a+b c /(c+k)$, where: $\mathrm{k}=$ estimated rate of passage of solids in the rumen and how the actual passage rate was not determined. The effective degradability for each concentrate and silage was estimated with solids passage rates of 2, 5 and $8 \% \mathrm{~h}^{-1}$. These were attributed, respectively, to the low, medium and high level of food intake where "a" is the readily degradable portion in the rumen, obtained through the differences between the quantity initially contained in the sample and that determined in the residue after washing and drying; " $b$ " is the insoluble but potentially degradable fraction; " $c$ " is the non-degradable fraction, considered the residue found in the TNT bag after $72 \mathrm{~h}$ of rumen permanence. 
The experimental design used for $\mathrm{pH}$ and $\mathrm{N}-\mathrm{NH}_{3}$ was a $5 \times 5$ Latin square, with five treatments and five periods, in a splitplot scheme, with the portion referring to the treatments $(100 \%$ C, $75 \%$ C 25\% WM, 50\% C 50\% WM, 25\% C 75\% WM, and 100\% WM) and the subplots at the collection times $(0,2$, 4,6 , and 8 h) according to the model: Yijk $=\mu$ $+\mathrm{Ai}+\mathrm{Pj}+\mathrm{Tk}+$ eijk $+\mathrm{Hm}+\mathrm{Tk} \times \mathrm{Hm}+$ eijkm, where $\mu$ = average, $\mathrm{Ai}=$ animal, $\mathrm{Pj}=$ period, $\mathrm{Tk}$ = treatment, eijk = plot error, $\mathrm{Hm}=$ effect of the time of harvest, $\mathrm{Tk} \times \mathrm{Hm}=$ effect of the interaction between treatment and harvest time and eijkm = experimental error.

For in vitro degradability, the experimental design was a $5 \times 5$ Latin square, with five treatments $(100 \%$ C, $75 \%$ C, 25\% WM, $50 \%$ C, 50\% WM, 25\% C, 75\% WM, and 100\% WM) and five periods of 25 days, following the model: $Y i j k=\mu+A i+P j+T k+E i j k$, where $A i=$ animal, $\mathrm{Pj}=$ period, $\mathrm{Tk}=$ treatment, and $\mathrm{Eijk}=$ experimental error.

The data were subjected to analysis of variance, and the differences between the treatment means and collection times were evaluated using polynomial regression analysis. Statistical analyses of the data were performed using the statistical software $\mathrm{R}$ (R CORE TEAM [R], 2013), and the level of significance was set at $5 \%$. The data were approved in the tests of homogeneity of variances (Bartlett) and normality of residues (Shapiro-Wilk).

\section{Results and Discussion}

The substitution of corn by wheat middling did not influence the $\mathrm{pH}$ or ruminal $\mathrm{N}-\mathrm{NH}_{3}$ of the cattle (Table 4). The ruminal $\mathrm{pH}$ averages were 6.45 (100\% C), 6.27 (75\% C 25\% WM), 6.27 (50\% C 50\% WM), 6.27 (25\% C $75 \% \mathrm{WM}$ ) and 6.05 (100\% WM). The averages of $\mathrm{N}-\mathrm{NH}_{3}$ in the rumen fluid were $5.18(100 \% \mathrm{C})$, 5.15 (75\% C 25\% WM), 4.75 (50\% C 50\% WM), 5.13 (25\% C 75\% WM) and 5.10 (100\% WM).

The average $\mathrm{pH}$ and $\mathrm{N}-\mathrm{NH}_{3}$ of the ruminal fluid of cattle were influenced by the collection time (Figure 1). The ruminal $\mathrm{pH}$ showed a quadratic behavior in relation to the collection time $(0,2,4,6$, and $8 \mathrm{~h})$, where the lowest $\mathrm{pH}$ value obtained (6.04) was at $4.32 \mathrm{~h}$ after feeding. According to Silva and Leão (1979), this drop after feeding is due an increased concentration of volatile fatty acids (AGV) in the rumen and a decrease in the buffering effect of saliva (rich in sodium bicarbonate, with a $\mathrm{pH}$ of approximately 8.1). Usually, in concentrated diets, the $\mathrm{pH}$ decreases between $30 \mathrm{~min}$ and $4 \mathrm{~h}$ after feeding, reflecting changes in the amount of volatile fatty acids formed and the buffer action of saliva. The maintenance of ruminal $\mathrm{pH}$ between 6.0 and 7.0 favors the development of cellulolytic microorganisms; however, the maximum activity is observed at a pH close to 6.2 (D'Aurea et al., 2017). 
Table 4

Average values of hydrogen potential $(\mathrm{pH})$ and ammoniacal nitrogen $\left(\mathrm{N}-\mathrm{NH}_{3}\right.$ in $\left.\mathrm{mg} \mathrm{dL}^{-1}\right)$ in the ruminal fluid, before ( 0 hours) and after feeding $(2,4,6$ and 8 hours)

\begin{tabular}{|c|c|c|c|c|c|c|c|}
\hline \multirow{2}{*}{$\begin{array}{l}\text { Time } \\
\text { (Hours) }\end{array}$} & \multicolumn{5}{|c|}{ Substitutions of corn by wheat middling ${ }^{1}$} & \multirow[b]{2}{*}{ Mean } & \multirow[b]{2}{*}{ CV (\%) } \\
\hline & $100 \% \mathrm{C}$ & $\begin{array}{c}75 \% \text { C } \\
25 \% \text { WM }\end{array}$ & $\begin{array}{c}50 \% \text { C } \\
50 \% \text { WM }\end{array}$ & $\begin{array}{c}25 \% \text { C } \\
75 \% \text { WM }\end{array}$ & $100 \% \mathrm{WM}$ & & \\
\hline \multicolumn{8}{|c|}{$\mathrm{pH}$} \\
\hline 0 & 6.59 & 6.74 & 6.46 & 6.76 & 6.64 & 6.64 & 7.09 \\
\hline 2 & 6.35 & 6.19 & 6.09 & 6.08 & 5.80 & 6.10 & 7.68 \\
\hline 4 & 6.37 & 5.99 & 5.96 & 6.06 & 5.81 & 6.04 & 7.36 \\
\hline 6 & 6.53 & 6.14 & 6.39 & 6.15 & 5.89 & 6.22 & 6.01 \\
\hline 8 & 6.40 & 6.28 & 6.44 & 6.31 & 6.10 & 6.30 & 5.35 \\
\hline Mean & 6.45 & 6.27 & 6.27 & 6.27 & 6.05 & 6.26 & 7.44 \\
\hline \multicolumn{8}{|c|}{$\mathrm{N}-\mathrm{NH}_{3}$ in $\mathrm{mg} \mathrm{dL} \mathrm{h}^{-1}$} \\
\hline 0 & 4.92 & 5.26 & 4.54 & 5.34 & 5.24 & 5.06 & 9.83 \\
\hline 2 & 5.72 & 5.75 & 5.45 & 6.08 & 6.17 & 5.84 & 6.69 \\
\hline 4 & 5.33 & 5.07 & 4.56 & 4.82 & 5.03 & 4.96 & 11.05 \\
\hline 6 & 4.98 & 4.96 & 4.53 & 4.52 & 4.59 & 4.71 & 9.61 \\
\hline 8 & 4.94 & 4.69 & 4.64 & 4.91 & 4.46 & 4.73 & 12.03 \\
\hline Mean & 5.18 & 5.15 & 4.75 & 5.13 & 5.10 & 5.06 & 12.61 \\
\hline
\end{tabular}

${ }^{1} 100 \%$ C = 100\% corn; $75 \%$ C 25\% WM = 75\% corn and 25\% wheat middling; $50 \%$ C 50\% WM = 50\% corn and 50\% wheat middling; $25 \%$ C $75 \%$ WM $=25 \%$ corn and $75 \%$ wheat middling; $100 \%$ WM $=100 \%$ wheat middling; CV = coefficient of variation; $\mathrm{p}$-value $(\mathrm{pH})=0.109 ; \mathrm{p}$-value $\left(\mathrm{N}-\mathrm{NH}_{3}\right)=0.110$.

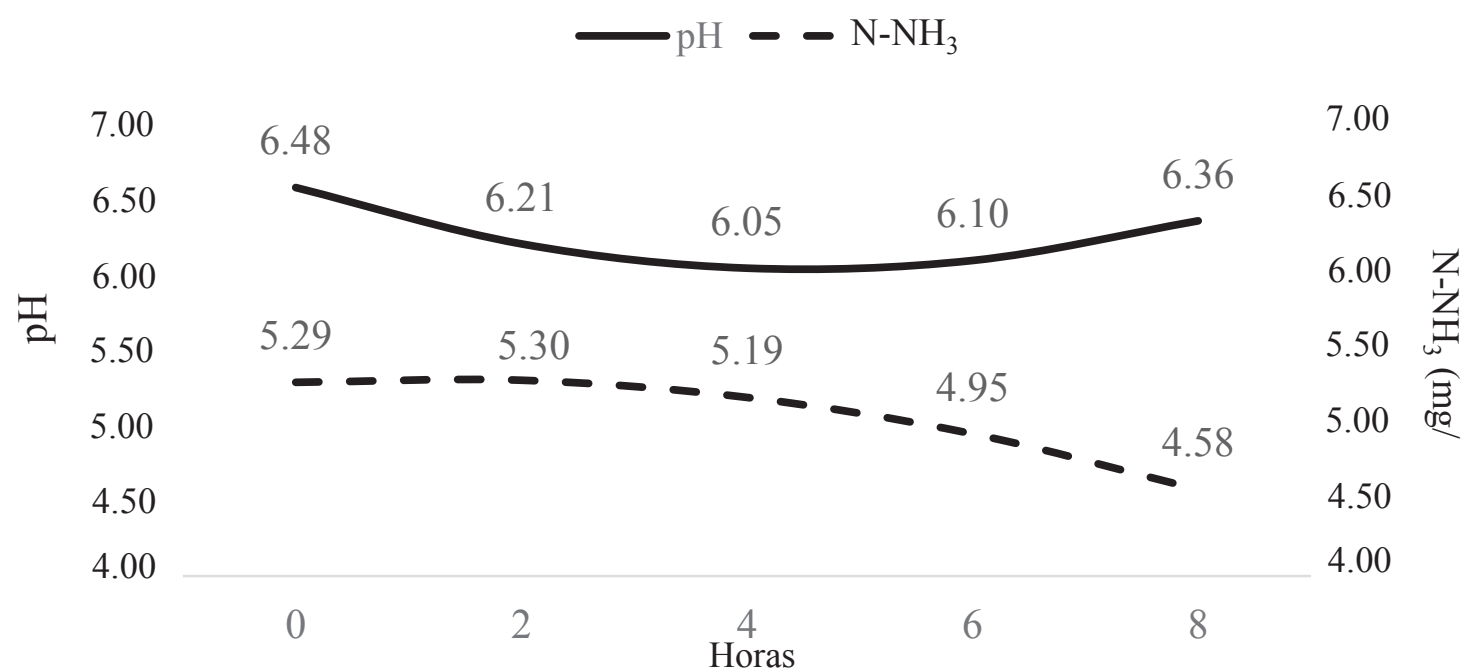

Figure 1. Average $\mathrm{pH}$ and $\mathrm{N}-\mathrm{NH}_{3}$ values of experimental diets at different collection times.

Hydrogen potential $(\mathrm{pH})=6.5841-0.2405 \mathrm{x}+0.0266 \mathrm{x}^{2}\left(\mathrm{R}^{2}=0.85\right), p$-value $=<0.001$, minimum point $=4 \mathrm{~h} 32$ and mean $=6.04$; ammoniacal nitrogen $\left(\mathrm{N}-\mathrm{NH}_{3}\right)=5.2884+0.0389 \mathrm{x}-0.0160 \mathrm{x}^{2}\left(\mathrm{R}^{2}=0.44\right)$, $p$-value $=0.0165$, maximum point $=1 \mathrm{~h} 12$ and mean $=5.31 \mathrm{mgdL}^{-1}$. 
On the other hand, 4h32 after feed intake, the pHincreased progressively, reaching a value of $6.368 \mathrm{~h}$ after feeding, because of a decrease in the rumen substrate, physiological removal of rumen acids, and the consequent decrease in concentration AGV. This process is caused by the rumen mechanisms, salivary activity and absorption of volatile fatty acids, by the ruminal epithelium (Geron et al., 2015). This decrease in the mean $\mathrm{pH}$ value, which occurred after feeding, should not be an obstacle in the use of wheat middling in concentrated diets, even those with a higher concentrate/roughage ratio. This is because alternatives, such as the use of additives that assist in stabilizing ruminal pH (Safaei, Tahmasbi, \& Moghaddam, 2014), microorganism control (ionophores) or by direct action on the rumen-produced acids (sodium bicarbonate), are available and can be utilized because of the lower cost of the coproduct in relation to corn.

$\mathrm{N}-\mathrm{NH}_{3}$ showed a quadratic behavior with the amount of corn substitution by wheat middling with a maximum concentration in the rumen at $1 \mathrm{~h} 12$ after feeding, where an average of $5.31 \mathrm{mg} \mathrm{dL}^{-1}$ was observed. According to Ferreira et al. (2015), the concentration of ammoniacal nitrogen in the rumen is a consequence of the balance between its production, absorption, and use by microorganisms, which is the main source of nitrogen for the synthesis of microbial protein. However, ruminal fermentation of the protein produces more ruminal $\mathrm{N}-\mathrm{NH} 3$ that microorganisms can use.

From $1 \mathrm{~h} 12$ after feeding, N-NH3 started to decrease, the opposite behavior to $\mathrm{pH}$. Costa et al. (2015) pointed out that the availability of carbohydrates promotes an increase in rumen energy and a consequent decrease in $\mathrm{pH}$, allowing greater use of ammonia for microbial growth. Thus, there is a reduction in the concentration of $\mathrm{N}-\mathrm{NH}_{3}$.

The observed values indicate that the feed rations were adequate to provide good ruminal digestion of dry matter, where

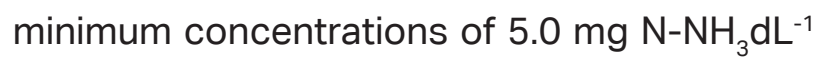
are necessary for the maximization of consumption (Vieira etal., 2017). The availability of energy and nitrogen for microorganisms is determined by the rates of digestion and passage through the rumen, which influences the efficiency of microbial protein synthesis and animal performance.

The values obtained for the soluble fraction $(A)$, potentially degradable insoluble (B), indigestible $(C)$, degradation rate $(k d)$, potential degradability (DP), and effective degradability (DE) with a passage rate of 2,5 , and $8 \% \mathrm{~h}^{-1}$ of DM are shown in Table 5. Fractions $A, B$, and $C$, the rate of degradation and effective degradability of DM were influenced by the replacement of corn by wheat middling. 


\section{Table 5}

Soluble fraction (A), insoluble potentially degradable fraction (B), indigestible fraction (C), rate of degradation (kd), potential degradability (DP) and effective degradability (DE) of the dry matter of the diets incubated in the rumen

\begin{tabular}{|c|c|c|c|c|c|c|c|}
\hline \multirow[b]{2}{*}{ (\%) } & \multicolumn{5}{|c|}{ Substitutions of corn by wheat middling ${ }^{1}$} & \multirow[b]{2}{*}{$p$-value } & \multirow{2}{*}{$\begin{array}{l}\text { CV } \\
\text { (\%) }\end{array}$} \\
\hline & $100 \% \mathrm{C}$ & $\begin{array}{c}75 \% \text { C } \\
25 \% \text { WM }\end{array}$ & $\begin{array}{c}50 \% \text { C } \\
50 \% \text { WM }\end{array}$ & $\begin{array}{c}25 \% \text { C } \\
75 \% \text { WM }\end{array}$ & $100 \% \mathrm{WM}$ & & \\
\hline A & 12.83 & 13.35 & 13.88 & 14.40 & 14.93 & $<0.001$ & 6.53 \\
\hline B & 59.50 & 57.02 & 55.67 & 55.44 & 56.33 & 0.028 & 5.14 \\
\hline C & 27.48 & 29.68 & 30.51 & 29.96 & 28.03 & 0.019 & 8.56 \\
\hline $\mathrm{kd}\left(\% \mathrm{~h}^{-1}\right)$ & 2.85 & 3.20 & 3.56 & 3.91 & 4.26 & 0.011 & 26.24 \\
\hline DP & 63.34 & 61.69 & 64.90 & 64.22 & 65.57 & 0.206 & 5.47 \\
\hline DE 2 & 46.19 & 47.54 & 48.89 & 50.24 & 51.59 & 0.021 & 7.34 \\
\hline DE 5 & 33.76 & 35.41 & 37.04 & 38.68 & 40.32 & 0.005 & 9.98 \\
\hline DE 8 & 28.16 & 29.74 & 31.33 & 32.92 & 34.51 & 0.002 & 10.77 \\
\hline
\end{tabular}

${ }^{1} 100 \% \mathrm{C}=100 \%$ corn; $75 \%$ C $25 \% \mathrm{WM}=75 \%$ corn and $25 \%$ wheat middling; 50\% C 50\% WM $=50 \%$ corn e 50\% wheat middling; $25 \% \mathrm{C} 75 \% \mathrm{WM}=25 \%$ corn and $75 \%$ wheat middling; $100 \% \mathrm{WM}=100 \%$ wheat middling; DE 2, DE 5 e DE 8 $=$ Effective degradability with $2,5 \mathrm{e} 8 \% \mathrm{~h}^{-1}$ as pass rate values; $C V=$ Coefficient of variation; $A=\hat{y}=12.8295+0.0212 \times\left(R^{2}\right.$ $=0.92) ; B=\hat{y}=59.5013-0.1217 x+0.0009 x^{2}\left(R^{2}=0.91\right)$, Minimum point $=67.6 \% ; C=\hat{y}=27.4850+0.1155 x-0.0011 x^{2}\left(R^{2}\right.$ $=0.93)$, Maximum point $=52.5 \% ; k d=\hat{y}=2.8515+0.0141 \times\left(R^{2}=0.65\right) ; D E 2=\hat{y}=46.1951+0.0540 \times\left(R^{2}=0.82\right) ; D E 5=\hat{y}$ $=33.7651+0.0656 x\left(R^{2}=0.86\right) ; D E 8=\hat{y}=28.1579+0.0635 x\left(R^{2}=0.88\right)$.

Fraction A of DM showed linear behavior and increased from $12.83 \%$ to $14.40 \%$. Fraction B of DM showed a quadratic behavior with an average of $55.38 \%$ at the minimum replacement point of $67.6 \%$, and fraction $\mathrm{C}$ of DM showed a quadratic behavior, with a maximum point in the replacement of $52.5 \%$ of corn by wheat middling, where an average of $30.51 \%$ was observed.

According to Goes et al. (2012), the greatest ruminal disappearance at time zero is due to the greater presence of watersoluble compounds. Wheat middling has small granules with an average diameter of $6 \mu \mathrm{m}$, while small granules of corn have an average diameter of $12.12 \mu \mathrm{m}$. Small granules are more susceptible to hydrolysis than large granules, suggesting that the enzymatic susceptibility of small granules is related to their larger surface area, which may have promoted the increase in fraction $A$ of $M S, M O$, and $P B$ as the levels of wheat middling contents increased.

The DM degradation rate showed a positive linear behavior, with an increase from $2.85 \% \mathrm{~h}^{-1}$ to $4.26 \% \mathrm{~h}^{-1}$ between treatments $100 \% \mathrm{C}$ and $100 \%$ WM, respectively. However, the potential degradability of DM was not influenced by the replacement of corn with wheat middling, with an average of $63.94 \%$.

The effective degradability (DE) of DM with 2,5 , and $8 \% \mathrm{~h}^{-1}$ of passage rate were influenced by the replacement of corn by wheat middling, and increasing linear behaviors were observed. The DE $2 \% \mathrm{~h}^{-1}$ of the DM varied from $46.19 \%$ to $50.24 \%$, while the DE $5 \% \mathrm{~h}^{-1}$ of the DM varied from $33.76 \%$ to $38.68 \%$ and the DE $8 \% \mathrm{~h}^{-1}$ of DM showed values from $28.16 \%$ to 
$32.92 \%$ for the treatments with $100 \% \mathrm{C}$ and $100 \%$ WM. These higher values, obtained in the treatments with higher contents of corn substitution by wheat middling, occurred because of the lower content of fiber (Table 3) and the highest soluble fractions and DM degradation rate (Table 5 ) in the rations with wheat middling.

The effective degradability decreased as the passage rate increased, and this result is related to the shorter time the food remains in the rumen, thus reducing the time that ruminal microorganisms remain in contact with the food particles.

The soluble, insoluble fraction potentially degradable, indigestible, rate of degradation, potential degradability, and effective degradability with passage rates of 2,5 , and $8 \% \mathrm{~h}^{-1}$ of OM (Table 6 ) were also influenced by the substitution of corn for wheat middling.

\section{Table 6}

Soluble fraction (A), insoluble potentially degradable fraction (B), indigestible fraction (C), rate of degradation (kd), potential degradability (DP) and effective degradability (DE) of the organic matter of the diets incubated in the rumen

\begin{tabular}{|c|c|c|c|c|c|c|c|}
\hline \multirow[b]{2}{*}{ (\%) } & \multicolumn{5}{|c|}{ Substitutions of corn by wheat middling ${ }^{1}$} & \multirow[b]{2}{*}{$p$-value } & \multirow[b]{2}{*}{$\begin{array}{l}\text { CV } \\
\text { (\%) }\end{array}$} \\
\hline & $100 \% \mathrm{C}$ & $\begin{array}{c}75 \% \text { C } \\
25 \% \text { WM }\end{array}$ & $\begin{array}{c}50 \% \text { C } \\
50 \% \text { WM }\end{array}$ & $\begin{array}{c}25 \% \text { C } \\
75 \% \text { WM }\end{array}$ & $100 \% \mathrm{WM}$ & & \\
\hline A & 8.45 & 9.27 & 10.09 & 10.91 & 11.73 & $<0.001$ & 12.66 \\
\hline B & 62.07 & 64.41 & 64.87 & 63.46 & 60.17 & $<0.001$ & 2.95 \\
\hline C & 29.05 & 26.53 & 25.51 & 25.99 & 27.97 & $<0.001$ & 5.25 \\
\hline $\mathrm{kd}\left(\% \mathrm{~h}^{-1}\right)$ & 2.61 & 3.31 & 3.63 & 3.58 & 3.16 & $<0.001$ & 11.75 \\
\hline DP & 60.34 & 64.06 & 65.77 & 65.49 & 63.20 & $<0.001$ & 3.18 \\
\hline DE 2 & 39.28 & 43.53 & 45.66 & 45.67 & 43.55 & $<0.001$ & 5.43 \\
\hline DE 5 & 30.55 & 34.66 & 36.77 & 36.88 & 34.98 & $<0.001$ & 6.74 \\
\hline DE 8 & 24.76 & 28.29 & 30.21 & 30.49 & 29.16 & $<0.001$ & 7.41 \\
\hline
\end{tabular}

${ }^{1} 100 \% \mathrm{C}=100 \%$ corn; $75 \%$ C 25\% WM $=75 \%$ corn and $25 \%$ wheat middling; 50\% C 50\% WM = 50\% corn e 50\% wheat middling; $25 \% \mathrm{C} 75 \% \mathrm{WM}=25 \%$ corn and $75 \%$ wheat middling; $100 \% \mathrm{WM}=100 \%$ wheat middling; DE 2 , DE 5 e DE 8 = Effective degradability with 2,5 e $8 \% h^{-1}$ as pass rate values; $C V=$ Coefficient of variation; $A=\hat{y}=8.452+0.0328 x$ $\left(R^{2}=0.85\right) ; B=\hat{y}=62.0713+0.1310 x-0.0015 x^{2}\left(R^{2}=0.87\right)$, Maximum point $=43.7 \% ; C=\hat{y}=29.0481-0.1308 x+0.0012 x^{2}$ $\left(R^{2}=0.89\right)$, Minimum point $=54.5 \% ; k d=\hat{y}=2.6067+0.0355 x-0.0003 x^{2} \quad\left(R^{2}=0.99\right)$, Maximum point $=59.2 \% ; D P$ $=\hat{y}=60.3440+0.1886 x-0.0016 x^{2}\left(R^{2}=0.93\right)$, Maximum point $=58.9 \% ; D E 2=\hat{y}=39.2792+0.2127 x-0.0017 x^{2}\left(R^{2}=\right.$ $0.98)$, Maximum point $=62.6 \%$; $D E 5=\hat{y}=30.5535+0.2043 x-0.0016 x^{2}\left(R^{2}=0.98\right)$, Maximum point $=63.8 \% ; D E 8=\hat{y}$ $=24.7581+0.1740 x-0.0013 x^{2}\left(R^{2}=0.97\right)$, Maximum point $=66.9 \%$.

Fraction A of OM showed positive linear behavior and ranged from 8.45 to $11.73 \%$. Fractions $B$ and $C$ of $O M$ presented quadratic behavior. A maximum point was observed in the replacement of $43.7 \%$ of wheat middling and an average of $64.93 \%$ for fraction $B$ and a minimum point in the substitution of $54.5 \%$ with an average of $25.48 \%$ for fraction C. 
The rate of degradation, potential degradability, and effective degradability of $\mathrm{OM}$ at passage rates of 2,5 , and $8 \% \mathrm{~h}^{-1}$ showed a quadratic behavior.
Fractions $A, B, C, k d\left(\% h^{-1}\right), D P$, and $\mathrm{DE} 2,5$, and 8 of CP were influenced by the replacement of corn by wheat middling in the diets (Table 7).

\section{Table 7}

Soluble fraction (A), insoluble potentially degradable fraction (B), indigestible fraction (C), rate of degradation (kd), potential degradability (DP) and effective degradability (DE) of the crude protein of the diets incubated in the rumen

\begin{tabular}{|c|c|c|c|c|c|c|c|}
\hline \multirow[b]{2}{*}{ (\%) } & \multicolumn{5}{|c|}{ Substitutions of corn by wheat middling ${ }^{1}$} & \multirow[b]{2}{*}{$p$-value } & \multirow{2}{*}{$\begin{array}{l}\text { CV } \\
\text { (\%) }\end{array}$} \\
\hline & $100 \% \mathrm{C}$ & $\begin{array}{c}75 \% \text { C } \\
25 \% \text { WM }\end{array}$ & $\begin{array}{c}50 \% \text { C } \\
50 \% \text { WM }\end{array}$ & $\begin{array}{c}25 \% \text { C } \\
75 \% \text { WM }\end{array}$ & $100 \% \mathrm{WM}$ & & \\
\hline$A$ & 24.27 & 26.60 & 28.93 & 31.26 & 33.58 & $<0.001$ & 15.04 \\
\hline B & 45.57 & 43.33 & 41.10 & 38.86 & 36.63 & $<0.001$ & 11.25 \\
\hline C & 31.69 & 29.29 & 28.50 & 29.35 & 31.85 & $<0.001$ & 5.07 \\
\hline $\mathrm{kd}\left(\% \mathrm{~h}^{-1}\right)$ & 2.52 & 2.58 & 2.52 & 2.34 & 2.03 & $<0.001$ & 4.45 \\
\hline DP & 62.73 & 65.53 & 66.71 & 66.27 & 64.20 & $<0.001$ & 2.46 \\
\hline DE 2 & 45.68 & 49.17 & 51.28 & 52.02 & 51.38 & $<0.001$ & 5.06 \\
\hline DE 5 & 39.25 & 42.85 & 45.07 & 45.92 & 45.39 & $<0.001$ & 6.78 \\
\hline DE 8 & 34.80 & 38.49 & 40.92 & 42.11 & 42.04 & $<0.001$ & 8.47 \\
\hline
\end{tabular}

${ }^{1} 100 \%$ C $=100 \%$ corn; $75 \%$ C 25\% WM $=75 \%$ corn and $25 \%$ wheat middling; $50 \%$ C 50\% WM = 50\% corn e 50\% wheat middling; $25 \% \mathrm{C} 75 \% \mathrm{WM}=25 \%$ corn and $75 \%$ wheat middling; $100 \% \mathrm{WM}=100 \%$ wheat middling; DE 2 , DE 5 e DE 8 $=$ Effective degradability with 2,5 e $8 \% \mathrm{~h}-1$ as pass rate values; $C V=$ Coefficient of variation; $A=\hat{y}=24.2737+0.0931 x$ $\left(R^{2}=0.56\right) ; B=\hat{y}=45.5675-0.0894 x\left(R^{2}=0.44\right) ; C=\hat{y}=31.6959-0.1288 x+0.0013 x^{2}\left(R^{2}=0.79\right)$, Minimum point = 49.5\%; $k d=\hat{y}=2.5198+0.0051 x-0.0001 x^{2}\left(R^{2}=0.80\right)$, Maximum point $=25.5 \% ; D P=\hat{y}=62.7279+0.1447 x-0.0013 x^{2}\left(R^{2}=\right.$ 0.86), Maximum point $=55.6 \% ; \mathrm{DE} 2=\hat{y}=45.6840+0.1670 x-0.0011 x^{2}\left(R^{2}=0.83\right)$, Maximum point $=75.9 \% ; D E 5=\hat{y}=$ $39.2532+0.1714 x-0.0011 x^{2}\left(R^{2}=0.76\right)$, Maximum point $=77.9 \%$; $D E 8=\hat{y}=34.8058+0.1724 x-0.0010 x^{2}\left(R^{2}=0.74\right)$, Maximum point $=86.2 \%$.

Fraction A of CP showed positive linear behavior and varied from $24.27 \%$ to $33.58 \%$, while fraction $\mathrm{B}$ of $\mathrm{PB}$ decreased with the replacement of the briquette and varied from $45.57 \%$ to $38.86 \%$. Fraction C of CP showed a quadratic behavior with an average of $28.5 \%$ with a minimum point in the substitution of $49.5 \%$; the $k d\left(\% \mathrm{~h}^{-1}\right)$ of PB showed a quadratic behavior, indicating that the maximum rate of degradation occurred in the substitution of
$25.5 \%$, a moment when there may have been a greater synchronicity in the release of energy and protein in the rumen, where a degradation rate of $2.58 \%$ per hour was found.

The potential degradability of PB showed a quadratic behavior with a maximum point in the replacement of $55.6 \%$ of corn by wheat middling and an average of $66.75 \%$. The inconstant availability of $\mathrm{N}$ implies a worse ruminal utilization of the other nutritional 
components, where less degradation reduces the amount of $\mathrm{N}$ available for metabolism and a consequent reduction in microbial protein synthesis (Garcez et al., 2016). Despite the increase in DM degradability, diets with wheat middling above $55.6 \%$ need to be adjusted with protein sources of greater degradability to improve DP of BP and, consequently, balance the supply of protein and energy of the same fractions in the rumen.

The effective degradability of $\mathrm{CP}$ for pass rates of 2,5 , and $8 \% \mathrm{~h}^{-1}$ was influenced by the briquette content and presented a quadratic behavior with maximum points of $75.9 \%, 77.9 \%$, and $86.2 \%$ of substitution, respectively. When energy is available, rumen microorganisms turn non-protein nitrogen and degrade proteins into microbial proteins. The availability of energy and nitrogen for microorganisms is determined by the rate of degradation and the rate of passage of food through the rumen, in addition to influencing the efficiency and the amount of synthesized microbial protein.

The increase in passage rates allowed greater use of wheat middling flour without impairing the effective degradability of BP. According to Miranda et al. (2015), when protein degradation rates are very high, ruminal microorganisms may not use all the released amino acids and ammonia, which results in greater degradation than protein synthesis.

Fractions $A, B, C, k d\left(\% h^{-1}\right), S D$, and $D E$ 2,5 , and 8 of the NDF were influenced by the replacement of corn by wheat middling in the rations (Table 8). The NDF fraction A showed a linear behavior, and the values decreased from 9.41 to $9.15 \%$. The NDF fraction B was not influenced and presented an average of $51.57 \%$. NDF fraction C presented a quadratic model with a maximum replacement point of $44.0 \%$, where an average of $39.23 \%$ was observed. The NDF degradation rate presented a quadratic model, with a maximum point of $43.0 \%$ replacement, where an average of $4.61 \%$ per hour was observed. The NDF PD showed a decreasing linear behavior, varying from 58.36 to $57.87 \%$, and the increase in the content of brown rice in the diets resulted in a decrease in NDF. NDF DE 2, 5, and $8 \% \mathrm{~h}^{-1}$ showed quadratic behavior with averages of $41.60 \%, 33.43 \%$, and $27.76 \%$ and maximum points for substitutions of $29.6 \%, 34.7 \%$, and $35.2 \%$, respectively. This behavior can be explained by the reduction in the amount of soybean meal in the diets (Table 1) and, consequently, the quality of the NDF, stimulated by the increase in the content of wheat. 
Table 8

Soluble fraction (A), potentially degradable insoluble fraction (B), indigestible fraction (C), rate of degradation (kd), potential degradability (DP) and effective degradability (DE) of the neutral detergent fiber of the diets incubated in the rumen

\begin{tabular}{|c|c|c|c|c|c|c|c|}
\hline \multirow[b]{2}{*}{ (\%) } & \multicolumn{5}{|c|}{ Substitutions of corn by wheat middling ${ }^{1}$} & \multirow[b]{2}{*}{$p$-value } & \multirow{2}{*}{$\begin{array}{l}\text { CV } \\
(\%)\end{array}$} \\
\hline & $100 \% \mathrm{C}$ & $\begin{array}{c}75 \% \text { C } \\
25 \% \text { WM }\end{array}$ & $\begin{array}{c}50 \% \text { C } \\
50 \% \text { WM }\end{array}$ & $\begin{array}{c}25 \% \text { C } \\
75 \% \text { WM }\end{array}$ & $100 \% \mathrm{WM}$ & & \\
\hline A & 9.41 & 9.35 & 9.28 & 9.22 & 9.15 & $<0.001$ & 1.06 \\
\hline B & 51.81 & 51.36 & 51.14 & 51.96 & 51.62 & 0.0734 & 0.60 \\
\hline $\mathrm{C}$ & 38.84 & 39.15 & 39.22 & 39.03 & 38.60 & $<0.001$ & 0.85 \\
\hline $\mathrm{kd}\left(\% \mathrm{~h}^{-1}\right)$ & 4.24 & 4.54 & 4.60 & 4.41 & 3.96 & $<0.001$ & 8.44 \\
\hline DP & 58.36 & 58.20 & 58.03 & 57.87 & 57.71 & $<0.001$ & 0.57 \\
\hline DE 2 & 41.17 & 41.60 & 41.40 & 40.58 & 39.13 & $<0.001$ & 1.89 \\
\hline DE 5 & 32.83 & 33.39 & 33.32 & 32.62 & 31.30 & $<0.001$ & 2.60 \\
\hline DE 8 & 27.14 & 27.70 & 27.65 & 26.96 & 25.66 & $<0.001$ & 3.06 \\
\hline
\end{tabular}

${ }^{1} 100 \% \mathrm{C}=100 \%$ corn; $75 \%$ C $25 \% \mathrm{WM}=75 \%$ corn and $25 \%$ wheat middling; 50\% C 50\% WM $=50 \%$ corn e 50\% wheat middling; $25 \% \mathrm{C} 75 \% \mathrm{WM}=25 \%$ corn and $75 \%$ wheat middling; $100 \% \mathrm{WM}=100 \%$ wheat middling; DE 2 , DE 5 e DE $8=$ Effective degradability with 2,5 e $8 \% h^{-1}$ as pass rate values; $C V=$ Coefficient of variation; $A=\hat{y}=9.4118-0.0026 x$ $\left(R^{2}=0.95\right) ; C=\hat{y}=38.8404+0.0176 x-0.0002 x^{2}\left(R^{2}=0.21\right)$, Maximum point $=44.0 \% ; k d=\hat{y}=4.2409+0.0172 x-0.0002 x^{2}$ $\left(R^{2}=0.81\right)$, Maximum point $=43.0 \% ; D P=\hat{y}=58.3658-0.0066 x\left(R^{2}=0.49\right) ; D E 2=\hat{y}=41.1712+0.0296 x-0.0005 x^{2}\left(R^{2}=\right.$ 0.95), Maximum point $=29.6 \%$; DE5 $=\hat{y}=32.8322+0.0347 x-0.0005 x^{2}\left(R^{2}=0.94\right)$, Maximum point $=34.7 \%$; DE8 $=\hat{y}=$ $27.1366+0.0352 x-0.0005 x^{2}\left(R^{2}=0.92\right)$, Maximum point $=35.2 \%$.

Fractions $A, B, C, k d\left(\% h^{-1}\right), D P$, and $D E$ 2,5 , and 8 of the FDA were influenced by the replacement of corn by wheat in the rations (Table 9). Fraction A of the FDA showed a linear behavior, and the values decreased from $9.41 \%$ to $9.15 \%$. Fraction B of the FDA showed a linear behavior and decreased with the increase in the content of wheat in substitution for corn, varying from 43.09 to $41.66 \%$ for treatments $100 \% \mathrm{C}$ and $100 \% \mathrm{WM}$ (Table 9), which was related to higher amounts of FDA and lignin present in diets with higher corn contents (Table 3). Fraction $\mathrm{C}$ of the FDA presented a linear model, ranging from 47.88 to $50.62 \%$. The rate of degradation of the FDA presented a quadratic model, with a maximum point of $24.5 \%$ replacement of corn by wheat, with an average of $3.91 \%$ per hour. The FDA PD showed a linear decrease in substitution levels and ranged from 49.72 to $46.91 \%$. The FDA's effective degradability for 2,5 , and $8 \% \mathrm{~h}^{-1}$ ticket rates showed a decreasing linear behavior. 
Table 9

Soluble fraction (A), potentially degradable insoluble fraction (B), indigestible fraction (C), rate of degradation (kd), potential degradability (DP) and effective degradability (DE) of acid detergent fiber from rations incubated in the rumen

\begin{tabular}{|c|c|c|c|c|c|c|c|}
\hline \multirow[b]{2}{*}{ (\%) } & \multicolumn{5}{|c|}{ Substitutions of corn by wheat middling ${ }^{1}$} & \multirow[b]{2}{*}{$p$-value } & \multirow{2}{*}{$\begin{array}{l}\text { CV } \\
\text { (\%) }\end{array}$} \\
\hline & $100 \% \mathrm{C}$ & $\begin{array}{c}75 \% \mathrm{C} \\
25 \% \mathrm{WM}\end{array}$ & $\begin{array}{c}50 \% \text { C } \\
50 \% \text { WM }\end{array}$ & $\begin{array}{c}25 \% \mathrm{C} \\
75 \% \mathrm{WM}\end{array}$ & $100 \%$ WM & & \\
\hline A & 9.12 & 8.89 & 8.65 & 8.41 & 8.18 & $<0.001$ & 4.12 \\
\hline B & 43.09 & 42.61 & 42.13 & 41.66 & 41.18 & $<0.001$ & 1.78 \\
\hline $\mathrm{C}$ & 47.88 & 48.56 & 49.25 & 49.93 & 50.62 & $<0.001$ & 2.08 \\
\hline $\mathrm{kd}\left(\% \mathrm{~h}^{-1}\right)$ & 3.86 & 3.92 & 3.85 & 3.66 & 3.35 & $<0.001$ & 2.36 \\
\hline DP & 49.72 & 49.02 & 48.32 & 47.61 & 46.91 & $<0.001$ & 2.13 \\
\hline DE 2 & 34.96 & 34.41 & 33.85 & 33.29 & 32.73 & $<0.001$ & 2.38 \\
\hline DE 5 & 27.75 & 27.24 & 26.72 & 26.21 & 25.70 & $<0.001$ & 2.92 \\
\hline DE 8 & 23.06 & 22.62 & 22.18 & 21.74 & 21.30 & $<0.001$ & 2.89 \\
\hline
\end{tabular}

${ }^{1} 100 \% \mathrm{C}=100 \%$ corn; $75 \%$ C $25 \% \mathrm{WM}=75 \%$ corn and $25 \%$ wheat middling; 50\% C 50\% WM $=50 \%$ corn e 50\% wheat middling; $25 \% \mathrm{C} 75 \% \mathrm{WM}=25 \%$ corn and $75 \%$ wheat middling; $100 \% \mathrm{WM}=100 \%$ wheat middling; DE 2, DE 5 e DE 8 $=$ Effective degradability with 2,5 e $8 \% h^{-1}$ as pass rate values; $C V=$ Coefficient of variation; $A=\hat{y}=9.1285-0.0095 \times\left(R^{2}\right.$ $=0.96) ; B=\hat{y}=43.0878-0.0191 x\left(R^{2}=0.83\right) ; C=\hat{y}=47.8810+0.0274 x\left(R^{2}=0.93\right) ; k d=\hat{y}=3.858+0.0049 x-0.0001 x^{2}\left(R^{2}\right.$ $=0.87$ Maximum point $=24.5 \% ; D P=\hat{y}=49.7221-0.0281 \times\left(R^{2}=0.97\right) ; D E 2=\hat{y}=34.9638-0.0223 \times\left(R^{2}=0.99\right) ; D E 5=\hat{y}=$ $27.7475-0.0205 \times\left(R^{2}=0.99\right) ; D E 8=\hat{y}=23.0560-0.0176 \times\left(R^{2}=0.98\right)$.

\section{Conclusion}

Wheat middling can be used as a total replacement for corn without damaging the $\mathrm{pH}$ and rumen $\mathrm{N}-\mathrm{NH}_{3}$, in addition to improving the degradability of the feed.

\section{References}

Cappelle, E. R., Valadares, S. C., Fo., Silva, J. F. C., \& Cecon, R. (2001). Estimativas do valor energético a partir de características químicas e bromatológicas dos alimentos. Revista Brasileira de Zootecnia, 30(6), 1837-1856. doi: 10.1590/s1516-3598200 1000700022

Costa, N. L., Monteiro, A. L. G., Silva, A. L. P., Moraes, A., Giostri, A. F., Stivari, T. S. S., Pin, E. E. (2015). Considerações sobre a degradação da fibra em forragens tropicais associada com suplementos energéticos ou nitrogenados. Archivos de Zootecnia, 64(R), 31-41. doi: 10.21071/ az.v64i247.504

D'Aurea, A. P., Ezequiel, J. M. B., D'Aurea, E. M. O., Fávaro, V. R., Homem, A. C., Jr., Van Cleef, E. H. C. B.,... Almeida, M. T. C. (2017). Glicerina associada à ureia na terminação de bovinos: parâmetros ruminais, digestibilidade e massa microbiana. Arquivo Brasileiro de Medicina Veterinária e Zootecnia, 69(1), 146-154. doi: 10.1590 /1678-4162-8896

Fenner, H. (1965). Method for determining total volatile bases in rumen fluid by steam destilation. Journal of Dairy Science, 48(2), 249-251. doi: 10.3168/jds.S00220302(65)88206-6 
Ferreira, S. F., Fernandes, J. J. R., Pádua, J. T., Bilego, U. O., Lima, M. A. S., França, A. F. S. Grandini, D. (2015). Desempenho e metabolismo ruminal em bovinos de corte em sistema de pastejo no período seco do ano recebendo virginiamicina na dieta. Semina: Ciências Agrárias, 36(3), 2067-2078. doi: 10.5433/16790359.2015v36n3Supl1p2067

Garcez, B. S., Alves, A. A., Araujo, D. L. C., Lacerda, M. S. B., Sousa, L. G. C., \& Carvalho, L. F. (2016). Degradabilidade ruminal do capim colonião (Panicum maximum Jacq. cv. Colonião) em três idades pós-rebrota. Acta Veterinaria Brasilica, 10(2), 130-134. doi: 10.21708/avb.2016.10.2.5513

Geron, L. J. V., Garcia, J., Costa, F. G., Aguiar, S. C., Oliveira, E.B., Silva, M.I.L., Mexia,A.A.(2015). Ruminal parameters and nitrogen balance in sheep fed diets containing residue from the extraction of tamarind pulp. Semina: Ciências Agrárias, 36(5), 3411-3420. doi: 10.5433/1679-0359.2015v36n5p3411

Goes, R. H. T. B., Tramontini, R. C. M., Cardim, S. T., Almeida, G. D., Ribeiro, J., Morotti, F., Brabes, K. C. S. (2012). Degradação ruminal da matéria seca e de proteína bruta de volumosos para bovinos. Revista Acadêmica de Ciências Agrárias e Ambientais, 10(3), 285-291. doi: 10.7213/ academica.7709

Miranda, P. A. B., Fialho, M. P. F., Saliba, E. O. S., Oliveira, L. O. F., Costa, H. H. A., Lopes, V. E. S., \& Silva, J. J. (2015). Consumo, degradabilidade in situ e cinética ruminal em bovinos suplementados com diferentes proteinados. Arquivo Brasileiro de Medicina Veterinária e Zootecnia, 67(2), 573-582. doi: 10.1590/1678-6934
Mizubuti, I. Y., Pinto, A. P. P., Ramos, B. M. O., \& Pereira, E. S. (2009). Métodos laboratoriais de avaliação de alimentos para animais. Londrina, PR: EDUEL.

Mizubuti,I.Y., Ribeiro, E.L.A.,Pereira,E.S.,Peixoto, E. L. T., Moura, E. S., Prado, O. P. P. P., Cruz, J. M. C. (2014). Cinética de degradação ruminal de alimentos proteicos pela técnica in vitro de produção de gases. Semina: Ciências Agrárias, 35(1), 555-566. doi: 10.5433/1679-0359.2014v35n1p555

Muniz, E. B., Mizubuti, I. Y., Pereira, E. S., Pimentel, P. G., Ribeiro, E. L. A., \& Pinto, A. P. (2012). Cinética ruminal da fração fibrosa de volumosos para ruminantes. Revista Ciência Agronômica, 43(3), 604-610. doi: 10.1590/S1806-66902012000300025

National Research Council (1996). Nutrient requeriments of beef cattle (7th ed.). Washington, DC: National Academy Press.

Ørskov, E. R., \& McDonald, I. (1979). The estimation of protein degradability in the rumen from incubation measurementes weighted according to rate of passage. Journal of Agricultural Science, 92(2), 449503. doi: $10.1017 / s 0021859600063048$

Playne, M. J., \& McDonald, P. (1966). The buffering constituents of herbage and of silage. Journal of the Science of Food and Agriculture, 17(6), 264-268. doi: 10.1002/ jsfa.2740170609

R Core Team (2013). A language and environment for statistical computing. Vienna, Austria: R Foundation for Statistical Computing.

Safaei, K., Tahmasbi, A. M., \& Moghaddam, G. (2014). Effects of high concentrate:forage ratio diets containing monensin on the 
management of ruminal acidosis in Gezhel lambs. Small Ruminant Research, 121(2-3), 183-187. doi: 10.1016/j. smallrumres.2014.08.007

Silva, J. F. C., \& Leão, M. (1979). Fundamentos de Nutrição de Ruminantes. Piracicaba, SP: Livroceres.

Silva, S.P., \&Silva, M. M.C. (2013). Fracionamento de carboidratos e proteínas segundo o sistema CNCPS. Veterinária Notícias, 19(2), 95-108.

Silva-Marques, R. P., Zervoudakis, J. T., Hatamoto-Zervoudakis, L. K., Cabral, L. S., Alexandrino, E., José, A., Neto, Melo, A. C. B. (2015). Suplementos múltiplos para novilhos de corte a pasto no período seco: características nutricionais. Semina: Ciências Agrárias, 36(1), 509-524. doi: 10.5433/1679-0359.2015 v36n1p509
Socreppa, L. M., Moraes, E. H. B. K., Moraes, K. A. K., Oliveira, A. S., Drosghic, L. C. A. B., Botini, L. A., \& Stinguel, H. (2015). Glicerina bruta para bovinos de corte em pastejo no período das águas: viabilidade produtiva e econômica. Revista Brasileira de Saúde e Produção Animal, 16(1), 232-243. doi: 10.1590/S1519-99402015000100024

Van Soest, P. J. (1994). Nutritional ecology of the ruminant. Ithaca, NY: Cornell University Press.

Vieira, P. A. S., Azevêdo, J. A. G., Silva, F. F., Pereira, L. G. R., Neves, A. L. A., Santos, A. B., Santos, R. D. (2017). Parâmetros ruminais e balanço de nitrogênio em bovinos alimentados com silagem da raiz de mandioca. Pesquisa Veterinária Brasileira, 37(8), 883-890. doi: 10.1590/ S0100-736X2017000800018 